\title{
ANALISIS PERTIMBANGAN HAKIM DALAM MEMUTUS KASUS TINDAK PIDANA PENYELUNDUPAN IKAN KE LUAR WILAYAH PENGELOLAAN PERIKANAN PROVINSI BANTEN (Studi Putusan Nomor 286/Pid.Sus/2018/PN Kla)
}

\author{
Eko Wibowo Adi Susilor, Abi Hasan Muan², Suta Ramadan ${ }^{3}$ \\ Fakultas Hukum Universitas Bandar Lampung \\ Jl. ZA Pagar Alam No 26 Labuhan Ratu Bandar Lampung \\ Email : ekowibowo484@gmaail.com; abi.muan@ublac.id; \\ suta.ramadan@ubl.ac.id
}

\begin{abstract}
ABSTRAK
Indonesia masih belum mampu menghentikan penyelundupan benih lobster atau benur di dalam negeri maupun luar negeri. Aktivitas terlarang tersebut, hingga saat ini masih aktif dilakukan oknum di berbagai pulau, tak terkecuali di pulau Jawa dan Sumatra.

Permasalahan penelitian adalah Bagaimanakah pertanggung jawaban pelaku tindak pidana penyelundupan ikan ke luar wilayah pengelolaan perikanan Republik Indonesia, Bagaimanakah pertimbangan Hakim dalam menjatuhkan putusan perkara terhadap pelaku tindak pidana penyelundupan ikan ke luar wilayah pengelolaan perikanan Republik Indonesia.

Metode penelitian yang digunakan pendekatan normatif dan empiris menggunakan data sekunder dan primer, data diperoleh dari studi lapangan, studi pustaka, dan selanjutnya dilakukan analisis secara yuridis kualitatif.

Berdasarkan hasil penelitian, dalam hal pertanggungjawaban pidana menjurus kepada pemidanaan pelaku, jika melakukan suatu tindak pidana dan memenuhi unsur-unsur yang telah ditentukan oleh undang-undang. Dilihat dari terjadinya perbuatan yang terlarang, ia akan diminta pertanggungjawaban apabila perbutan tersebut melanggar hukum. Dilihat dari sudut kemampuan bertanggungjawab maka hanya orang yang mampu bertanggungjawab yang dapat diminta pertanggungjawaban. Dasar pertimbangan hakim dalam Putusan Nomor 286/Pid.Sus/2018/PN Kla. bahwa Majellis Hakim mempertimbangkan dari berbagai unsur yaitu dakwaan Jaksa Penuntut umum, mengenai tindak pidana penyelundupan ikan ke luar wilayah pengelolaan perikanan Republik Indonesia yang telah memenuhi unsur di Pasal 88 Jo pasal 16 ayat (1) Undang-Undang RI Nomor 45 tahun 2009 tentang Perubahan atas Undang-undang RI nomor 31 tahun 2004 tentang Perikanan Jo Pasal 55 ayat (1) Ke-1 KUHP. Pertimbangan hakim selanjutnya dilihat dari unsur para pihak yang mana terdakwa bersikap koorperatif selama persidangan menimbulkan pertimbangan bagi hakim atas pernyataanpernyataannya.

Saran yang dapat penulis sampaikan adalah Penegak hukum (Polda Lampung) dan Dinas Balai Karantina Ikan Lampung seharusnya terlebih dahulu memetakan dan sosialisasi terhadap masyarakat khusunya terkait tindak pidana perikanan dalam penjualan bibit benur tanpa izin, kemudian penegak hukum harus lebih berani melakukan penegakan hukum secara tegas. Pemerintah baik daerah maupun pusat harus memperhatikan masalah terkait kurangnya sumber daya manusia dalam hal
\end{abstract}


ini yaitu para penegak hukum, kurangnya sarana dan fasilitas yang memadai, agar dapat lebih maksimal dalam penegakan hukum terhadap tindak pidana perikanan dalam penjualan bibit benur tanpa izin sehingga kerusakan pada ekosistem laut bahkan membahayakan serta terjadi kelangkaan ekosistem dapat terhindar.

Kata kunci : Pertimbangan Hakim, Bibit Benur, Tindak Pidana, Penyelundupan

\section{Pendahuluan}

\section{A. Latar Belakang}

Tindak pidana penggelapan di Indonesia saat ini menjadi salah satu penyebab terpuruknya sistem kesejahteraan material yang mengabaikan nilai-nilai kehidupan dalam masyarakat. Kehidupan masyarakat sedikit demi sedikit mulai berubah, penghormatan atas nilai-nilai hukum yang ada mulai bergeser, masyarakat mulai berfikir materialistis dan egois dalam menghadapi kehidupan ini, hal ini juga menyebabkan mulai melemahnya rasa kepercayaan masyarakat terhadap sesama individu.

Tindak pidana penggelapan merupakan suatu tindak pidana yang berhubungan dengan kepercayaan dan harta kekayaaan. Tindak pidana penggelapan diatur dalam Buku Kedua Bab XXIV Pasal 372, Pasal 373, Pasal 374, Pasal 375, Pasal 376, dan Pasal 377 Kitab Undang-Undang Hukum Pidana. Penggelapan dengan segala macam bentuknya merupakan suatu jenis tindak pidana yang cukup berat bila dilihat dari akibat yang ditimbulkan dan pengaruhnya terhadap masyarakat. Hal tersebut berbanding lurus dengan upaya pemberantasannya, yang semakin berat untuk dilakukan. ${ }^{1}$

Salah satu kasus penggelapan yang terjadi dalam perkara yang diputus Pengadilan Negeri Serang, dimana terdakwa Edi Sunardi Bin Rohim selaku karyawan PT. Dover Chemical yang bertugas sebagai foreman loading di area depot B PT. Dover Chemical di Jalan raya Merak Km. 116 Kelurahan Gerem Kecamatan Gerogol Kota Cilegon. Terdakwa Edi Sunardi Bin Rohim Bersama-Sama Dengan Saksi Kokoh Dwi Cahyo bin (Alm) Muhammad Amin Rahman, saksi Yunus Suparman Bin Sadiman dan saksi Heri Suprianto bin Sukarman (yang masing-masing penuntutannya dilakukan secara terpisah), telah melakukan, yang menyuruh melakukan, dan yang turut serta melakukan, dengan sengaja dan melawan hukum memiliki barang sesuatu yang seluruhnya atau sebagian adalah kepunyaan orang lain, tetapi yang ada dalam kekuasaannya bukan karena kejahatan, yang dilakukan oleh orang yang penguasaannya terhadap barang disebabkan karena ada hubungan kerja atau karena pencarian atau karena mendapat upah untuk itu, yang dilakukan terdakwa.
1 Sudarto. 1986. Hukum dan Hukum Pidana. Alumni, Bandung, hlm. 40. 
B. Permasalahan

1. Bagaimanakah

pertanggungjawaban pelaku tindak pidana dengan sengaja turut serta melakukan penggelapan dalam status jabatan perusahaan berdasarkan Putusan 73/Pid.B/2018/PN SRG?

2. Bagaimanakah pertimbangan hakim dalam memutus perkara pertanggungjawaban pelaku tindak pidana dengan sengaja turut serta melakukan penggelapan dalam status jabatan perusahaan berdasarkan Putusan 73/Pid.B/2018/PN SRG ?

\section{Pembahasan}

\section{A. Pengertian}

Pengaturan mengenai tindak pidana penggelapan menurut Pasal 374 KUHP adalah penggelapan yang dilakukan oleh orang yang penguasaannya terhadap barang disebabkan karena ada hubungan kerja atau karena pencarian atau karena mendapat upah untuk itu, diancam dengan pidana penjara paling lama lima tahun. Pelaku tindak pidana itu adalah seseorang yang melakukan tindak pidana yang bersangkutan, dalam arti orang yang dengan suatu kesengajaan atau suatu yang tidak disengajakan seperti yang disyaratkan oleh undang-undang telah menimbulkan akibat yang tidak dilarang atau tindakan yang diwajibkaln oleh undang-undang. Dengan kata lain pelaku tindak pidana adalah orang yang memenuhi semua unsur-unsur suatu delik seperti yang telah ditentukan dalam undang-undang baik itu merupakan unsur-unsur subjektif ataupun unsurunsur objektif, tanpa memandang apakah keputusan untuk melakukan tindakan pidana tersebut timbul dari dirinya atau timbul karena digerakkan oleh pihak ketiga.

\section{B. Teori-Teori}

Sampai saat ini, pengertian hukum belum ada yang pasti. Atau dengan kata lain, belum ada sebuah pengertian hukum yang dijadikan standar dalam memahami makna dan konsep hukum. ${ }^{2}$ Notohamidjojo mendefinisikan hukum adalah sebagai keseluruhan peraturan yang tertulis dan tidak tertulis yang biasanya bersifat memaksa, untuk kelakuan manusia dalam masyarakat negara (serta antar negara), yang mengarah kepada keadilan, demi terwujudnya tata damai, dengan tujuan memanusiakan manusia dalam masyarakat. ${ }^{3}$ Sedangkan menurut Soedarto pidana adalah penderitaan yang sengaja di bebankan kepada orang yang melakukan perbuatan yang memenuhi syarat-syarat tertentu. ${ }^{4}$

Pengertian Hukum Pidana menurut para ahli Menurut W.P.J Pompe, hukum pidana adalah semua aturan hukum yang menentukan terhadap tindakan apa yang seharusnya dijatuhkan pidana dan apa macam pidananya yang bersesuaian. Menurut Moeljatno, hukum pidana adalah bagian dari keseluruhan hukum yang berlaku disuatu negara,

${ }^{2}$ Ranidar Darwis. 2003. Pendidikan Hukum dalam Konteks Sosial Budaya bagi Pembinaan Kesadaran Hukum Warga Negara, Departemen Pendidikan Indonesia UPI, Bandaung, hlm. 6 .

3 O. Notohamidjojo. 2011. SoalSoal Pokok Filsafat Hukum. Griya Media, Jakarta, hlm. 121.

${ }^{4}$ Muladi dan Barda Nawawi Arief. 2005. Teori-Teori dan Kebijakan Pidana. Alumni, Bandung, hlm. 2. 
yang mengadakan dasar- dasar aturan untuk:

a. Menentukan perbuatan perbuatan mana yang tidak boleh dilakukan, yang dilarang, dengan disertai ancaman atau sanksi berupa pidana tertentu bagi barangsiapa melanggar larangan tersebut (Criminal act);

b. Menentukan kapan dan dalam halhal apa kepada mereka yg telah melanggar larangan-larangan itu dapat dikenakan atau dijatuhi pidana sebagaimana yg telah diancamkan (Criminal Liability/ Criminal Responsibility);

c. Menentukan dengan cara bagaimana pengenaan pidana itu dapat dilaksanakan apabila ada orang yang disangka telah melanggar larangan tersebut (Criminal Procedurel Hukum Acara Pidana). ${ }^{5}$

Menurut Jan Remmelink, mengatakan hukum pidana mencakup hal-hal sebagai berikut:

a. perintah dan larangan yang atas pelanggaran terhadapnya oleh organ-organ yang dinyatakan berwenang oleh undang-undang dikaitkan (ancaman) pidana, normanorma yang harus ditaati oleh siapapun juga;

b. ketentuan-ketentuan yang menetapkan sarana-sarana apa yang dapat di daya gunakan sebagai reaksi terhadap pelanggaran normanorma itu, hukum penitensier atau lebih luas, hukum tentang sanski;

${ }^{5}$ Ibid. c. aturan-aturan yang secara temporal atau dalam jangka waktu tertentu menetapkan batas ruang lingkup kerja dari norma-norma. ${ }^{6}$

Tindak pidana adalah kelakuan manusia yang dirumuskan dalam undang-undang, melawan hukum, yang patut dipidana dan dilakukan dengan kesalahan. Orang yang melakukan perbuatan pidana akan mempertanggungjawabkan perbuatan dengan pidana apabila ia mempunyai kesalahan, seseorang mempunyai kesalahan apabila pada waktu melakukan perbuatan dilihat dari segi masyarakat menunjukan pandangan normatif mengenai kesalahan yang dilakukan. ${ }^{7}$ Tindak pidana adalah perbuatan melakukan atau tidak melakukan sesuatu yang memiliki unsur kesalahan sebagai perbuatan yang dilarang dan diancam dengan pidana, dimana penjatuhan pidana terhadap pelaku adalah demi terpeliharanya tertib hukum dan terjaminnya kepentingan umum. ${ }^{8}$

Moeljatno merumuskan unsur-unsur perbuatan pidana/tindak pidana sebagai

berikut:

1. Perbuatan (manusia);

2. Yang memenuhi rumusan dalam undang-undang (ini merupakan syarat formil); dan

3. Bersifat melawan hukum (ini merupakan syarat materil). ${ }^{9}$

${ }^{6}$ Remmelink. 2003. Hukum Pidana - Komentar atas pasal-pasal terpenting dari KUHP Belanda dan padannya dalam KUHP Indonesia. Gramedia Pustaka Utama, Jakarta, hlm. 1.

${ }^{7}$ Ibid, hlm. 8.

${ }^{8}$ Ibid, hlm. 13.

${ }^{9}$ Ibid, hlm. 70. 
Orang yang melakukan tindak pidana (yang memenuhi unsur-unsur tersebut tidak diatas) harus dapat dipertanggungjawabkan dalam hukum pidana agar dapat dipidana. Jadi unsur pertanggungjawaban pidana ini melekat pada orangnya/pelaku tindak pidana. Adapun unsur-unsur pertannggungjawaban pidana meliputi :

1. Kesalahan;

2. Kemampuan bertanggungjawab. ${ }^{10}$

Menurut Roeslan Saleh, pengertian perbuatan pidana tidak termasuk hal pertanggungjawaban. Perbuatan pidana hanya menunjuk kepada dilarangnya perbuatan. Apakah orang yang telah melakukan perbuatan itu kemudian juga dipidana, tergantung pada soal apakah dia dalam melakukan perbuatan itu memang mempunyai kesalahan atau tidak. Apabila orang yang melakukan perbuatan pidana itu memang mempunyai kesalahan, maka tentu dia akan dipidana".

Seorang hakim dalam hal menjatuhkan pidana kepada terdakwa tidak boleh menjatuhkan pidana tersebut kecuali apabila dengan sekurang-kurangnya dua alat bukti yang sah, sehingga hakim memperoleh keyakinan bahwa suatu tindak pidana benar-benar terjadi dan terdakwalah yang bersalah melakukannya (Pasal 183 KUHAP). Alat bukti sah yang dimaksud adalah:

1. Keterangan Saksi;

2. Keterangan Ahli;

3. Surat;

4. Petunjuk;

${ }^{10} \mathrm{Ibid}$.
5. Keterangan Terdakwa atau hal yang secara umum sudah diketahui sehingga tidak perlu dibuktikan (Pasal 184). ${ }^{11}$

\section{Pertanggungjawaban pelaku tindak pidana dengan sengaja turut serta melakukan penggelapan dalam status jabatan perusahaan}

Pertangungjawaban pidana adalah pertanggungjawaban dan pidana merupakan ungkapan-ungkapan yang terdengar dan digunakan dalam kehidupan sehari-hari, dalam moral, agama dan hukum. Tiga hal ini berkaitan dengan yang lain, dan berakar pada suatu keadaan yang sama, yaitu adanya suatu pelanggaran terhadap suatu pelanggaran dan suatu sistem aturanaturan.

Pertanggungjawaban pidana berkaitan dengan persoalan keadilan. Pertangggungjawaban pidana lahir dengan diteruskannya celaan yang objektif terhadap perbuatan yang dinyatakan sebagai tindak pidana berdasarkan hukum pidana yang berlaku, yang secara subjektif kepada pembuat yang memenuhi persyaratan untuk dapat dikenai pidana karena perbuatan tersebut. Dasar dari adanya tindak pidana adalah asas legalitas, sedangkan dasar dapat dipidananya pembuat adalah asas kesalahan. Ini berarti bahwa pembuat tindak pidana hanya akan dipidana jika ia mempunyai kesalahan dalam melakukan tindak pidana tersebut. Kapan seseorang dikatakan mempunyai kesalahan dalam melakukan tindak pidana tersebut,

${ }^{11}$ Satjipto Rahardjo, Bunga Rampai Permasalahan Dalam Sistem Peradilan Pidana, Pusat Pelayanan Keadilan dan Pengabdian Hukum, Jakarta, 1998, hlm. 11. 
merupakan hal menyangkut masalah pertanggungjawaban pidana. Seseorang mempunyai kesalahan bilamana melakukan tindak pidana, dilihat dari segi kemasyarakatan ia dapat dicela oleh karena perbuatan tersebut.

Kesalahan dalam pengertian seluasluasnya, yang dapat disamakan dengan pengertian pertanggungjawaban dalam hukum pidana, di dalamnya terkandung makna dapat dicelanya si pembuat atas perbuatannya. Jadi apabila dikatakan orang bersalah melakukan sesuatu tindak pidana, maka itu berarti bahwa ia dapat dicela atas perbuatannya.

Kesalahan dalam arti bentuk kesalahan (schuldvorm) dapat juga dikatakan kesalahan dalam arti yuridis, yang berupa pertama, kesengajaan, dan kedua, kealpaan. Unsur-unsur kesalahan (dalam arti yang seluas-luasnya), ialah:

1. Adanya kemampuan bertanggungjawab si pembuat; keadaan jiwa si pembuat harus normal;

2. Hubungan batin (geweten) antara si pembuat dengan perbuatannya, yakni berupa kesengajaan (dolus/opzet) atau kealpaaan (culpa/eenalaten); ini disebut bentuk-bentuk kesalahan;

3. Tidak adanya alasan yang menghapus kesalahan atau tidak adanya alasan pemaaf. Pertanggungjawaban pidana, ada suatu pandangan yaitu pandangan monistis dan pandangan yang dualistis.

Hal demikian dapat diketahui dengan diilustrasikan bunyi "barangsiapa ...." yang menunjukkan bahwa hanya seorang saja yang dapat mempertanggung jawabkan atas terlanggarnya perumusan delik itu. Jadi jelas bahwa setiap orang bertanggungjawab atas perbuatan melanggar hukum pidana secara sendiri-sendiri.

Dengan demikian menurut ketentuan tersebut bahwa ada 4 (empat) bentuk penyertaan perbuatan pidana yaitu menurut Pasa155 ayat (1) antara lain pelaku pelaksana (plegen); pembuat pelaku atau penyuruh (doen plegen); pelaku peserta (medeplegen); dan penganjur atau pembujuk atau perencana (uitlokken).

\section{Pertimbangan hakim dalam memutus perkara pertanggungjawaban pelaku tindak pidana dengan sengaja turut serta melakukan penggelapan dalam status jabatan perusahaan}

Majelis Hakim dalam menjatuhkan pidana kepada para terdakwa harus terlebih dahulu telah memenuhi semua syarat untuk dilakukan pemidanaan atas diri para terdakwa. Seperti dinyatakan oleh Sudarto, bahwa syarat untuk pemidanaan tersebut, adalah :

1. Perbuatan yang memenuhi rumusan undang-undang;

2. Yang bersifat melawan hukum (tidak ada alasan pembenar);

3. Adanya kesalahan yaitu :

a. mampu bertanggung jawab;

b. Dolus atau culpa (tidak ada alasan pemaaf)

Bendasarkan pada hasil penelitian terhadap Putusan Nomor 73/Pid.B/2018/PN SRG dan dengan melakukan studi pustaka tentang 
materi yang berhubungan dengan obyek penelitian serta mengacu pada pendapat Sudarto mengenai syaratsyarat pemidanaan, maka agar dapat menjawab permasalahan dan tujuan penelitian tersebut dapat disusun analisis sebagai berikut :

1. Adanya fakta yang terbukti dalam unsur-unsur Pasal 372 KUHP jo Pasal 55 ayat (1) ke 1 KUHP.

a. Perbuatan yang memenuhi rumusan undang-undang

2. Perbuatan yang dilakukan bersifat melawan hukum

3. Adanya kesalahan

\section{PENUTUP}

\section{A. Kesimpulan}

1. Pertanggungjawaban pelaku tindak pidana dengan sengaja turut serta melakukan penggelapan dalam status jabatan perusahaan dijerat Pasal 370 KUHP jo 55 KUHP karena terdakwa orang yang turut serta melakukan sebagian dari unsurunsur delik. Artinya terdakwa hanya melaksanakan sebagian saja dari unsurunsur delik dan bersama dengan temannya menyelesaikan delik itu.

2. Bahwa pertimbangan hakim dalam memutus perkara pertanggungjawaban pelaku tindak pidana dengan sengaja turut serta melakukan penggelapan dalam status jabatan perusahaan telah memenuhi semua syarat-syarat pemidanaan menurut teori Sudarto, dan putusan tersebut telah tepat dan adil kiranya pidana yang dijatuhkan terhadap diri Terdakwa. Sehingga memenuhi rasa keadilan.

\section{B. Saran}

1. Hakim dalam menjatuhkan pidana hendaknya mengacu kepada teori Sudarto tentang Pemidanaan agar setiap Putusan menimbulkan kepastian hukum dan keadilan

2. Pemilik Perusahaan hendaknya lebih selektif dan selalu control pekerja nya agal mempersempit ruang gerak pekerja yang berniat melakukan tindak pidana penggelapan.

\section{DAFTAR PUSTAKA}

\section{A. BUKU - BUKU}

Andi Zainal Abidin. 1993. Hukum Pidana I. Sinar Grafika, Jakarta.

Andi Hamzah. 2001. Bunga Rampai Hukum Pidana dan Acara Pidana. Ghalia Indonesia Jakarta.

Andi Hamzah. 2008. Asas-Asas Hukum Pidana. Rineka Cipta, Jakarta.

Agus Santoso. 2012. Hukum, Moral \& Keadilan. Kencana Prenada Media Group, Jakarta.

Bambang Waluyo. 2016. Penegakan Hukum Di Indonesia. Sinar Grafika, Jakarta.

Chairul Huda. 2006. Dari tiada pidana tanapa kesalahan menuju kepada tiada pertanggungjawaban 
pidana tanpa kesalahan. Prenada Media, Jakarta.

C.S.T. Kansil \& Christine S.T. Kansil. 2004. Pokok-Pokok Hukum Pidana, Hukum Pidana Untuk Tiap Orang. Pradnya Paramita, Jakarta.

Jimly Asshidiqie. 2014. Peradilan Etika dan Etika Konstitusi. Sinar Grafika, Jakarta.

Mahrus Ali. 2011. Dasar-Dasar Hukum Pidana. Sinar Grafika, Jakarta.

Moch. Anwar. 1986. Hukum Pidana Bagian Khusus. Alumni, Bandung.

Moeljatno. 2000. Asas-asas Hukum Pidana. Rineka Cipta, Jakarta.

Muladi dan Barda Nawawi Arief. 2005. Teori-Teori dan Kebijakan Pidana. Alumni, Bandung,

O. Notohamidjojo. 2011. Soal-Soal Pokok Filsafat Hukum. Griya Media, Jakarta.

P.A.F. Lamintang. 1996. DasarDasar Hukum Pidana Indonesia. Citra Adityta Bakti, Bandung.

Poernomo, Bambang. 2003. AsasAsas Hukum Pidana. Ghalia Indonesia, Jakarta.

Ranidar Darwis. 2003. Pendidikan Hukum dalam Konteks Sosial Budaya bagi Pembinaan Kesadaran Hukum Warga Negara, Departemen Pendidikan Indonesia UPI, Bandaung.
Remmelink. 2003. Hukum Pidana Komentar atas pasal-pasal terpenting dari KUHP Belanda dan padannya dalam KUHP Indonesia. Gramedia Pustaka Utama, Jakarta.

Ruslan Saleh. 1962. Stelsel Pidana Indonesia. Sinar Grafika, Jakarta.

Ruslan Saleh. 1983. Pikiran-pikiran Tentang

Pertanggungjawaban

Pidana. Ghalia Indonesia, Jakarta.

Satjipto Rahardjo. 1980. Hukum dan Masyarakat. Angkasa, Bandung.

Satjipto Rahardjo. 1998. Bunga Rampai Permasalahan Dalam Sistem Peradilan Pidana. Pusat Pelayanan Keadilan dan Pengabdian Hukum, Jakarta.

Siahaan, R.O. 2003. Hukum Pidana I. RAO Press, Cibubur.

Sudarto. 1986. Hukum dan Hukum Pidana. Alumni, Bandung.

Tri Adrisman. 2009. Hukum Pidana Asas-Asas Dan Dasar Aturan Umum Hukum Pidana Indonesia. Unila, Bandar Lampung,

Tri Andrisman. 2011. Hukum Pidana, Hukum Pidana: Asas-asas dan Dasar Aturan Umum Hukum Pidana Indonesia. Penerbit Universitas Lampung, Bandar Lampung. 


\section{B. UNDANG-UNDANG DAN PERATURAN LAIN}
Undang-Undang Dasar Negara Republik Indonesia Tahun 1945;

Undang-Undang Nomor 1 Tahun 1946 jo Undang-Undang Nomor 73 Tahun 1958 Tentang Kitab UndangUndang Hukum Pidana;

Undang-Undang Nomor 8 Tahun 1981 tentang Kitab UndangUndang Hukum Acara Pidana;

Undang-Undang Nomor 2 Tahun 2002 tentang Kepolisian Negara Republik Indonesia;

Undang-Undang Nomor 16 Tahun 2004 tentang Kejaksaan Republik Indonesia;

Undang-Undang Nomor 48 Tahun 2009 tentang Perubahan Atas Undang-Undang Nomor 4 Tahun 2004 tentang Kekuasaan Kehakiman Republik Indonesia;

Undang-Undang Nomor 16 Tahun 1992 tentang Karantina Hewan, Ikan, dan Tumbuhan;

Undang-Undang Nomor 45 Tahun 2009 tentang Perubahan Atas Undang-Undang Nomor 31 Tahun 2004 tentang Perikanan;

Peraturan Pemerintah Nomor 58 Tahun 2010 tentang Perubahan Atas Peraturan
Pemerintah Nomor 27

Tahun 1983 tentang

Pedoman Pelaksanaan Kitab

Undang-Undang Hukum

Acara Pidana;

Peraturan Pemerintah Nomor 15 Tahun 2002 tentang Karantina Ikan;

Peraturan Menteri Kelautan dan Perikanan Nomor 56/Permen-KP/2016 tentang Larangan Penangkapan dan/atau Pengeluaran Lobster (Panulirus Spp.), Kepiting (Scylla Spp.), dan Rajungan (Portunus Spp.) dari Wilayah Negara Republik Indonesia;

\section{SUMBER LAIN}

Departemen Pendidikan dan Kebudayaan, Kamus Besar Bahasa Indonesia, Balai Pustaka, Jakarta, Kamus Besar Bahasa Inggris. 